\title{
Psikolojik Sözleșmenin Oluşumu ve Kapsamına İlişkin Düşük Maaşla İstihdam Edilen Yeni Mezun Mühendisler ve Yöneticilerinin Algıları Üzerine Fenomenolojik Bir Araştırma $^{1}$
}

\author{
(Araştırma Makalesi)
}

\author{
A Phenomenological Research on the Perceptions of Low-Paid Newly \\ Graduated Engineers and Their Managers on the Formation and Scope of the \\ Psychological Contract
}

Doi: 10.29023/alanyaakademik.689313

\section{Nuray AKAR}

Dr. Ö̆gr. Üyesi, Akdeniz Üniversitesi, Uygulamalı Bilimler Fakültesi, Yönetim Bilişim Sistemleri Bölümü nurayyapici@akdeniz.edu.tr Orcid No: 0000-0003-2444-1233

Bu makale, Akdeniz Üniversitesi Sosyal ve Beşeri Bilimler Bilimsel Araştırma ve Yayın Etiği Kurulu'nun 02.03.2020 tarihli ve 55 sayll kararl ile fikri hukuki ve telif hakları bakımından etik olarak uygun bulunmuştur.

Bu makaleye atıfta bulunmak için: Akar, N. (2020). Psikolojik Sözleşmenin Oluşumu ve Kapsamına İlişkin Düşük Maaşla İstihdam Edilen Yeni Mezun Mühendisler ve Yöneticilerinin Algıları Üzerine Fenomenolojik Bir Araştırma. Alanya Akademik Bakış, 4(2), Sayfa No.173-192.

\begin{tabular}{|c|c|}
\hline \multirow{2}{*}{ Anahtar kelimeler: } & \\
\hline & u çalışmada, düşük maaşla istihdam edilen yeni mezun mühendislerin \\
\hline Psikolojik & psikolojik sözleşme kapsamında karşı taraf olarak kimi algıladıkları, \\
\hline $\begin{array}{l}\text { Psikolojik } \\
\text { Sözlesmeni }\end{array}$ & $\begin{array}{l}\text { rafların psikolojlk sozleşmeye daır algilarının nasıl oluştugu ve psikolojık } \\
\text { zleşme kapsamındaki karşılıklı beklenti ve yükümlülüklere ilişkin düşük }\end{array}$ \\
\hline Oluşumu, & aş̧la istihdam edilen yeni mezun mühendisler ile yöneticilerinin bakls \\
\hline $\begin{array}{l}\text { Çalışan Beklentileri, } \\
\text { İşveren Beklentileri, }\end{array}$ & $\begin{array}{l}\text { açıları araştırılmıştır. Bu doğrultuda nitel araşt } \\
\text { farklı alanlarda düşük maaşla istihdam edilen y }\end{array}$ \\
\hline Fenomenolojik & miş \\
\hline Araş & $\begin{array}{l}\text { cunda, } \\
\text { tihdam }\end{array}$ \\
\hline ah & $\begin{array}{l}\text { ezun mühendisler ile yöneticilerinin işlemsel ve ilişkisel } \\
\text { llgılara sahip olduğu tespit edilmiştir. }\end{array}$ \\
\hline
\end{tabular}

Kabul Tarihi:

03.05.2020

1 Bu çalışma, araştırmacı tarafından 9 Nisan 2010 tarihinde 1. Turizmde İnsan Kaynakları Gelişimi Sempozyumu'nda sunulan "Psikolojik Sözleşme İhlalleri Bağlamında Örgütsel Sinizm Üzerine Kuramsal Bir Araştırma” başlıklı bildiri, 3 Kasım 2017 tarihinde V. Örgütsel Davranış Kongresi’nde sunulan "Mavi Yakalı Çalışanların Psikolojik Sözleşmeye İlişkin Algılarının Oluşumu ve Kapsamı Üzerine Nitel Bir Araştırma” başlıklı bildiri ve 25 Kasım 2017 tarihinde Uluslararası Multidisipliner Çalışmaları Kongresi'nde sunulan "Işsverenler ile Mavi Yakalı Çalışanların Psikolojik Sözleşme Kapsamındaki Karşılıklı Beklenti ve Yükümlülüklerine Dair Algılarının Belirlenmesi ” başlıklı bildiri kapsamında yürütülen araştırmalar temel alınarak gerçekleştirilmiştir. 
Keywords:

\author{
Psychological \\ Contract, Formation \\ of the Psychological \\ Contract, Employee \\ Expectations, \\ Employer \\ Expectations, \\ Phenomenological \\ Research
}

\begin{abstract}
The purpose of this study is to research the low-paid newly graduated engineers perceive whom as the opposite party, how perceptions of the parties of psychological contract are formed and these engineers and their managers' mutual expectations and obligations under the psychological contract. Accordingly, using qualitative research design, semi-structured interviews were held with 15 low-paid newly graduated engineers who were employed in different fields and 11 managers of them. As a result of the phenomenological analysis, it was determined that the low-paid newly graduated engineers and their managers have transactional and relational based differences in their perceptions of formation and content of the psychological contract.
\end{abstract}

\section{GİRIŞ̧}

Araştırmacılar ve uygulamacılar uzun yıllardan beri çalışanlar ile işverenleri arasındaki ilişkilerin doğasını anlamaya çaba göstermektedirler. Bu doğrultuda tarafların karşılıklı beklenti ve yükümlülüklerine dair algılamaları temelinde biçimlenen psikolojik sözleşmeler, örgütsel davranış açısından istihdam ilişkilerinin kapsamını ve sürecini keşfetme imkânı sağlamaktadır. Robinson (1996: 575); psikolojik sözleşme kavramının kökenlerinin Argyris (1960), Levinson (1962) ve Schein'in (1980) çalışmalarına dayandığını ve istihdam ilişkilerinin öznel doğasının tanımlanması amacıyla kullanıldığını vurgulamaktadır. Bu bağlamda psikolojik sözleşme, istihdam ilişkisinin tarafları olarak örgüt ve çalışanın karşılıklı vaatler ve yükümlülükler hususundaki algılarını ifade etmektedir (Guest ve Conway, 2002). Söz konusu algılar, formel sözleşmelerin ya da tarafların birbirlerinden beklentilerinin bir yansıması olabilmektedir. Bu yaklaşım, tarafların her birinin söz konusu yükümlülüklerin ne olduğu konusunda farklı bir algıya sahip olabileceğine işaret etmektedir (Herriot vd., 1997: 151). Algısal niteliği dolayısıyla psikolojik sözleşmeler, işveren ve çalışan arasındaki istihdam ilişkisine bireysel düzeyde odaklanmaktadır. Bu temeldeki bir anlaşma zaman içinde yeniden müzakere edilebilmekte, değişebilmekte, çeşitli bağlamsal faktörlerden etkilenebilmekte ve farkl1 etkiler yaratabilmektedir (Guest, 2004).

Bu noktada Kotter (1973), söz konusu algıların işverenlerden çok çalışanlara ait olduğunu öne sürerek psikolojik sözleşme hususunda farklı bir yaklaşım sergilemektedir. Örgütlerde psikolojik sözleşme konusunda oldukça ses getiren ve kavramın ilgi odağı olmasına öncülük eden çalışmasında Rousseau (1989) da bu yaklaşımla psikolojik sözleşme kavramını, çalışan ile örgütü arasındaki karşılıklı mübadele anlaşmasının şartları ve koşullarına ilişkin çalışanın bireysel inançları olarak tanımlamıştır (s.123). Bu çerçevede psikolojik sözleşmenin, öznelliğine ve çalışanın örgütüne olan yükümlülükleri ile örgütün çalışana olan yükümlülüklerine dair çalışanın bireysel algılarına dayandığına dikkat çekilmektedir (Anderson ve Schalk, 1998: 639). Diğer bir ifadeyle çalışan işverene yüksek ücret ve iş güvenliği gibi belirli teşvikleri karşısında sıkı çalışma, sadakat ve özveri gibi katkılar sunmaya borçlu olduğunu düşündüğünde bireysel inançlar birer sözleşme yükümlülüğü hâline gelmektedir (Rousseau, 1990: 390). Psikolojik sözleşme kapsamının bu şekilde yalnızca çalışan kesim odaklı değerlendirilmesi, istihdam ilişkisine tüm yönleriyle 1şık tutmaması nedeniyle bazı yazarlar (Conway ve Briner, 2005; Guest, 2004) tarafından eleştirilmektedir. 
Bu doğrultuda, psikolojik sözleşme kapsamının karşılıklılık ilkesi temelinde hem çalışan hem de yönetici bakış açısından değerlendirilmesi gerekliliği vurgulanmaktadır (Coyle-Shapiro ve Kessler, 2002; Tekleab ve Taylor, 2003).

Karşılıklılık çerçevesinden bakıldığında, psikolojik sözleşme kapsamındaki işveren yükümlülüklerinin ücret, yan ödemeler, iş güvenliği, insani çalışma koşulları, çalışanlarla iletişim kurulması, onlara eğitim firsatları sunulması, örgütsel adalet sağlanması, başarıların takdir edilmesi gibi hususları içerdiği görülmektedir. Bu kapsamdaki çalışan yükümlülükleri arasında ise çalışma saatlerine riayet edilmesi, nitelik ve nicelik olarak iyi iş çıkarılması, örgüte karşı özenli davranılması, dürüstlük, bağlılık, esneklik gibi hususlar yer almaktadır (Herriot vd., 1997). Bu hâliyle psikolojik sözleşme kapsamındaki algılanan yükümlülükler, çalışanların örgütte nelerle karşılaşacaklarına ilişkin genel beklentilerinden farklılık göstermektedir. Örneğin; yeni bir yönetici yüksek maaş almayı, terfi ettirilmeyi, işini sevmeyi ya da çalışma ofisinin duvarlarının nötr bir renge boyanmış olmasını ümit edebilir. Bu beklentiler; geçmiş tecrübeler, sosyal normlar ya da arkadaşlar üzerinden yapılan gözlemler gibi çok çeşitli kaynaklardan ortaya çıkabilir. Diğer taraftan psikolojik sözleşmeler, çalışanların alma hakkına sahip olduklarını ya da almayı hak ettiklerini düşündükleri inançları kapsamaktadır. Çünkü çalışanlar, işverenlerinin bunları sağlamayı vaat ettiklerini algılamaktadırlar. Dolayısıyla yalnızca çalışanın işvereni tarafından belirgin ya da üstü kapalı bir biçimde verilen sözlere ilişkin algılamalarından doğan beklentiler psikolojik sözleşmenin bir parçası olmaktadır. Örneğin; yeni bir yönetici işe alım esnasında performans ile orantılı ödeme sözü aldığını düşündüğünde bu durum bir beklenti yarattığı gibi, aynı zamanda psikolojik sözleşmenin bir parçası olarak algılanmış bir yükümlülük de doğurmaktadır. Ancak her ne kadar psikolojik sözleşmeler bazı beklentiler yaratsa da tüm beklentiler algılanan vaatlerden doğmamakta ve algılanan vaatlerin ya da sözleşmelerin yokluğunda da bazı beklentiler oluşabilmektedir (Robinson, 1996: 575).

Psikolojik sözleşmenin taraflarının karşılıklı beklenti ve yükümlülüklerine odaklanıldığında, söz konusu sözleşmelerin genel olarak işlemsel ve ilişkisel olmak üzere iki boyutu kapsadığı görülmektedir. İşlemsel sözleşmeler; yüksek ücret, hızlı ilerleme ve performansa dayalı ücretlendirme gibi örgütsel teşvikler karşısında sıkı çalışma ve fazla mesai yapma gibi çalışan yükümlülüklerini içermektedir. İlişkisel sözleşmeler ise iş güvencesi, eğitim, kariyer geliştirme ve kişisel sorunlarla ilgili destek verilmesi gibi teşvikler karşısında; çalışanların örgütsel bağlılık göstermesi ve ekstra rol davranışı sergilemesi gibi yükümlülüklere işaret etmektedir. Dolayısıyla işlemsel sözleşmelerdeki mübadeleye maddi beklentiler ve ekonomik teşviklerin konu edildiği, ilişkisel sözleşmelerde ise daha çok duygusal beklentiler ve manevi teşviklerin söz konusu olduğu ifade edilebilir (Rousseau, 1990).

Yerli ve yabancı psikolojik sözleşme yazınında söz konusu olgunun doğası ya da içeriğinden daha çok kurulması, sürdürülmesi ve ihlal edilmesi süreçleri ile iş tatmini, işten ayrılma niyeti, personel devri, örgütsel bağlılık ve iletişim gibi örgütsel sonuçlar üzerine etkileri ve demografik değişkenlerle ilişkilerinin incelendiği görülmektedir (Aras vd., 2016; Herriot vd., 1997; Marks, 2001; Özdaşlı ve Çelikkol, 2012; Yapıcı-Akar, 2010). Oysaki psikolojik sözleşme kapsamındaki bireysel algı, beklenti ve inançların nasıl oluştuğu, çalışanların sözleşmenin karşı tarafı olarak zihinlerinde kimi konumlandırdığı ve tatminkâr bir istihdam ilişkisi açısından tarafların psikolojik sözleşme temelindeki karşılıklı beklenti ve yükümlülüklerine dair algılarının neleri içerdiği hususu da karmaşık bir görünüm arz etmektedir. Bu nedenle psikolojik sözleşme olgusunun doğasına yönelik derinlemesine bir 
anlayış geliştirilebilmesi adına, öncelikle psikolojik sözleşmelerin oluşum sürecinin ve kapsamının aydınlatılmasının büyük önem taşıdığı düşünülmektedir. Ayrıca psikolojik sözleşmenin bireysel algı ve yorumlamalara dayanmasının yanı sıra, istihdam ilişkilerinin dinamikleri bağlamında farklı çalışan grupları açısından oluşum sürecinin ve kapsamının değişiklik arz etmesi şaşırtıcı olmayacaktır. Dolayısıyla psikolojik sözleşme olgusuna yönelik bütünsel bir yapı sunulabilmesi için daha geniş kapsamlı bir bakış açısı ortaya konulması önem kazanmaktadır.

$\mathrm{Bu}$ ön saptamalar 1şı̆̆ında, söz konusu araştırmada çalışanların psikolojik sözleşme kapsamında karşı taraf olarak kimi algıladıklarının, tarafların psikolojik sözleşmeye dair algılarının nasıl oluştuğunun ve psikolojik sözleşme kapsamındaki karşılıklı beklenti ve yükümlülüklere ilişkin tarafların bakış açılarının incelenmesi amaçlanmıştır. Böylece yerli ve yabancı psikolojik sözleşme yazınındaki ilgili boşlukların doldurulmasına ve konunun derinlik kazanmasına katkı sağlanması beklenmektedir.

Bu doğrultuda araştırma soruları aşağıdaki gibi ifade edilmiştir:

1. Çalışanlar, psikolojik sözleşme kapsamında karşı taraf olarak kimi algılamaktadırlar?

2. Tarafların, psikolojik sözleşmeye dair algıları nasıl oluşmaktadır?

3. Taraflar, psikolojik sözleşme kapsamında birbirlerinden ne beklemektedirler?

4. Taraflar, psikolojik sözleşme kapsamında karşı tarafın kendilerinden ne beklediğini düşünmektedirler?

\section{YÖNTEM}

Psikolojik sözleşmenin algısal ve bireysel niteliğine rağmen, ilgili yazında yaygın olarak nicel araştırma yöntemlerinin kullanıldığı ve daha çok anketler aracılığıyla veri toplandığı dikkat çekmektedir (Aras vd., 2016; Conway ve Briner, 2005). Bu noktada Rousseau ve Tijoriwala (1998), bireysel inançlar ve yorumlamalara dayanması nedeniyle psikolojik sözleşmenin doğasını ve içeriğini anlamanın en kapsamlı yolunun, ilgili tarafların bu çerçevedeki algılarına yönelik kendileriyle doğrudan görüşülerek, etkileşim temelli ve derinlemesine veri toplanmasından geçtiğinin önemine işaret etmektedirler. $\mathrm{Bu}$ doğrultuda, psikolojik sözleşmenin oluşumu ve kapsamına ilişkin tarafların algılarının detaylı ve bütüncül bir biçimde ortaya konularak; bu algıların hangi bağlamsal koşullarda, nasıl biçimlendiğinin anlamlandırılmasına odaklanan bu çalışma, nitel araştırma tasarımlarından fenomenoloji deseninde gerçekleştirilmiştir.

Kökenleri, Husserl'in temelini attığı felsefi akıma dayanan fenomenolojik yaklaşım bir metodoloji olarak bireylerin herhangi bir sosyal olgu ile ilgili algı, yaşantı ve deneyimlerinin özünü anlamayı amaçlamaktadır (Husserl, 2010). Diğer bir ifadeyle, fenomenolojik araştırmada, öznelerin olguya ilişkin algı, yaşantı ve deneyimlerinin ne olduğu ve bunları etkileyen ortam ve koşulların neler olduğu temel sorularına yanıt aranarak; söz konusu algı, yaşantı ve deneyimlerin farklı bireyler açısından paylaşılan ortak anlamları açığa çıkarılmaya çalışılmaktadır (Moustakas, 1994). Bu kapsamda, fenomenolojik çalışmanın veri kaynağını, araştırmanın odaklandığı olguya ilişkin algılarını, yaşantılarını ve deneyimlerini paylaşma gönüllüğü gösteren bireyler ya da gruplar oluşturmaktadır (Yıldırım ve Şimşek, 2011). Fenomenolojik irdelemede araştırmacının rolü, söz konusu katılımcılar tarafından aktarılan 
ortak paylaşımlara odaklanarak, araştırılan olgu hakkındaki algıların, yaşantıların ve deneyimlerin özünü yansitan bir betimleme yapmaktır (Creswell, 2007).

Moustakas'ın (1994) betimleyici fenomenolojik yaklaşımında, araştırmacının ele alınan olguya yönelik bireysel yorum ve yargılarından arındırılmış, katılımcıların aktardıkları kişisel alg1, yaşantı ve deneyimlerin özünün korunması temelinde bir irdeleme yapılması önerilmektedir. Bu bağlamda, söz konusu betimleyici fenomenolojik yaklaşım; paranteze alma, fenomenolojik azaltma, yaratıcı dönüşüm, dokusal ve yapısal betimlemelerin oluşturulması ve birleştirilmesi aşamalarını içermektedir. Paranteze alma aşamasında araştırmacı, irdelenen olguya ilişkin bireysel algı, yaşantı ve deneyimlerini bir kenara bırakarak konuyla ilgili yargıda bulunmaktan kaçınmaktadır. Fenomenolojik azaltma aşamasında önemsiz, ilgisiz, farkında olmadan söylenen, odaklanılan olgu hakkındaki algı, yaşantı ve deneyimleri anlamlandırmaya katkı sağlamayan ve tekrar eden ifadeler elenmektedir. Yaratıcı dönüşüm aşamasında ortak ifadeler gruplanmakta ve belli temaları oluşturacak şekilde sınıflandırılmaktadır. Daha sonra katılımcıların ele alınan olguya yönelik algı, yaşantı ve deneyimlerinin ne olduğuna ilişkin dokusal ve bunların nasıl oluştuğuna ilişkin yapısal betimlemeler oluşturulmaktadır. Son aşamada ise söz konusu dokusal ve yapısal tanımlamalar birleştirilmekte ve ortak anlamlara ulaşılarak algı, yaşantı ve deneyimin özü açığa çıkarılmaktadır. Bu çalışmada, Moustakas'ın (1994) betimleyici fenomenolojik yaklaşımı benimsenmiş ve söz konusu fenomenolojik analiz süreci takip edilmiş̧ir.

\section{1. Çalışma Grubu}

Araştırmanın çalışma grubu, çok aşamalı örnekleme yöntemi kullanılarak oluşturulmuştur. $\mathrm{Bu}$ doğrultuda, ilk aşamada "çalışma yaşamında düşük maaşla istihdam edilen yeni mezun mühendis olmak" ölçüt olarak belirlenmiş ve amaçlı örnekleme yöntemlerinden ölçüt örnekleme temelinde seçim yapılmıştır. İkinci aşamada ise, konu hakkında en kapsamlı bilgiyi sunabilecek bireylerin tespit edilebilmesi adına kartopu örnekleme yöntemi kullanılmıştır. $\mathrm{Bu}$ aşamada, ilk olarak bireysel kariyer planlama süreçleri kapsamında tanışılmış olan ve düşük maaşla istihdam edilen yeni mezun üç mühendisle iletişime geçilerek, söz konusu araştırmaya gönüllü katılım sağlayabileceklerini belirtmeleri üzerine veri toplama sürecine başlanmıştır. Daha sonra bu üç katılımcının yönlendirdiği, örnekleme ölçütünü sağlayan ve irdelenen konuya ilişkin bilgi aktarma gönüllülüğü gösteren başka mühendislere ulaşılmıştır. Örneklem büyüklüğü açısından ise kuramsal örnekleme yaklaşımı benimsenmiş, katılımcı ifadelerinin tekrar etmeye başladığı ve artık yenilikler sunmadığ noktada veri toplama süreci sona erdirilmiştir. Bu doğrultuda, araştırmanın katılımcıları arasında psikolojik sözleşmenin taraflarından çalışan kesimini temsilen, farklı alanlarda düşük maaşla istihdam edilen yeni mezun 15 mühendis yer almıştır. Söz konusu mühendislerin 6'sı kadın, 9'u erkektir. Yaşları 22 ile 27 arasındadır. Henüz 1-2 yıllık iş deneyimine sahiptirler. Asgari ücretin 1,5 katı kadar maaş almaktadırlar. Çalışma grubundaki söz konusu mühendislere ilişkin bilgiler Tablo 1'de sunulmuştur. 
Tablo 1. Çalışma Grubundaki Düşük Maaşla İstihdam Edilen Yeni Mezun Mühendislere İlişkin

Bilgiler

\begin{tabular}{llll}
\hline Kod & Unvan & Cinsiyet & Sektör \\
\hline M1 & Endüstri Mühendisi & Kadın & Medikal \\
M2 & Endüstri Mühendisi & Erkek & Medikal \\
M3 & Kimya Mühendisi & Kadın & Kozmetik \\
M4 & Kimya Mühendisi & Erkek & Kozmetik \\
M5 & Makine Mühendisi & Erkek & Asansör \\
M6 & Mekatronik Mühendisi & Erkek & Asansör \\
M7 & Elektrik Mühendisi & Erkek & Asansör \\
M8 & Bilgisayar Mühendisi & Kadın & Turizm \\
M9 & Tekstil Mühendisi & Kadın & Hazır Giyim \\
M10 & G1da Mühendisi & Kadın & Toplu Yemek \\
M11 & Gıda Mühendisi & Erkek & Toplu Yemek \\
M12 & Ziraat Mühendisi & Erkek & Tarım \\
M13 & Çevre Mühendisi & Kadın & Çevre Danışmanlık Hizmetleri \\
M14 & İnşaat Mühendisi & Erkek & Mimarlık İnşaat Taahhüt \\
M15 & İnşaat Mühendisi & Erkek & Mimarlı İnşaat Taahhüt \\
\hline
\end{tabular}

Araştırmanın psikolojik sözleşmenin taraflarından işveren kesimini temsil eden katılımcılarının belirlenmesinde ise, çalışma grubu dâhilindeki farklı alanlarda düşük maaşla istihdam edilen yeni mezun mühendislerin psikolojik sözleşme kapsamında karşı taraf olarak kimi algıladıkları belirleyici olmuştur. Bu noktada, söz konusu mühendislerin psikolojik sözleşmenin karşı tarafı olarak yöneticilerini konumlandırdıkları saptanmıştır. Bu çerçevede, araştırmaya katılan mühendislerin işaret ettiği yöneticilerine ulaşılmış ve söz konusu araştırmaya gönüllü katılım sağlayabileceklerini belirten 11 yönetici çalışma grubuna dâhil edilmiştir. Bu aşamada, araştırma etiği ve gizlilik esası hususunda büyük bir titizlik ve hassasiyet gösterilerek çalışma grubundaki mühendislere yöneticilerinin, yöneticilere de mühendislerin kimliği açık edilmemiştir. Ayrıca kişi ve kurum isimlerine odaklanılmadığının, toplanan verilerin genel olarak değerlendirileceğinin altı çizilmiştir. Sonuç olarak taraflar birbirlerinden bağımsız ve habersiz olarak uygunluk, erişilebilirlik, gerçekleştirilebilirlik ve gönüllülük esasları temelinde araştırmanın çalışma grubunda yer almışlardır. Çalışma grubundaki yöneticilerin 5'i kadın, 6'sı erkektir. Bu yöneticilerden 2'si genel müdür, 2'si işletme müdürü, 4'ü birim yöneticisi ve 3'ü insan kaynakları yöneticisi pozisyonundadır. Söz konusu yöneticilere ilişkin bilgiler Tablo 2'de verilmiştir.

Tablo 2. Çalışma Grubundaki Yöneticilere İlişkin Bilgiler

\begin{tabular}{llll}
\hline Kod & Pozisyon & Cinsiyet & Sektör \\
\hline Y1 & İnsan Kaynakları Yöneticisi & Kadın & Medikal \\
Y2 & Birim Yöneticisi & Kadın & Medikal \\
Y3 & İnsan Kaynakları Yöneticisi & Erkek & Kozmetik \\
Y4 & Birim Yöneticisi & Kadın & Kozmetik \\
Y5 & Genel Müdür & Erkek & Asansör \\
Y6 & Birim Yöneticisi & Erkek & Turizm \\
Y7 & İnsan Kaynakları Yöneticisi & Kadın & Hazır Giyim \\
Y8 & Birim Yöneticisi & Kadın & Toplu Yemek \\
Y9 & İlstetme Müdürü & Erkek & Tarım \\
Y10 & İşletme Müdürü & Erkek & Çevre Danışmanlık Hizmetleri \\
Y11 & Genel Müdür & Erkek & Mimarlık İşaat Taahhüt \\
\hline
\end{tabular}




\subsection{Verilerin Toplanması ve Analizi}

Araştırma verileri yarı yapılandırılmış görüşme ile toplanmıştır. Görüşme soruları, temel araştırma soruları çerçevesinde hazırlanmıştır. Bireysel katılım onayları alınıp psikolojik sözleşme kavramı açıklanarak başlanan görüşmeler yaklaşık 45 ile 60 dakika arasında sürmüştür.

Veri analizi aşamasında, söz konusu görüşmeler deşifre edilerek bilgisayar ortamında yazılı hâle getirilmiştir. Bu çözümleme sonucunda oluşturulan ham veri metni içerik analizine tabi tutulmuş, kodlamalar yapılmış ve temalar belirlenmiştir. Araştırmanın geçerliliğinin artırılması adına etik prensipler ve gizlilik taahhüdü temelinde katılımcılarla güvene dayalı bir etkileşim sağlanmaya çalışılmıştır. Ayrıca araştırmanın gerçek durumu yansıtmasını sağlamak için talep eden katılımcılarla toplanan veriler ve ulaşılan sonuçlar paylaşılarak katılımcı teyidi alınmıştır. Araştırmanın güvenirliliği kapsamında toplanan verilerin doğasına sadık kalınmaya özen gösterilmiş ve katılımc1 ifadelerinin orijinalliği mümkün olduğunca korunmuştur. Ayrıca araştırmacı, tematik kodlamaya nihai hâlini verip temel kodları sabitledikten sonra dışarıdan ek kodlayıcılara başvurmuştur. Diğer taraftan bağımsız bir alan uzmanının, ham veriler ile ortaya çıkan temaları karşılaştırması temelinde bir inceleme yapılarak meslektaş teyidi de alınmıştır.

Bu makale, Akdeniz Üniversitesi Sosyal ve Beşeri Bilimler Bilimsel Araştırma ve Yayın Etiği Kurulu'nun 02.03.2020 tarihli ve 55 sayll kararl ile fikri hukuki ve telif hakları bakımından etik olarak uygun bulunmuştur.

\section{BULGULAR}

\subsection{Düşük Maaşla İstihdam Edilen Yeni Mezun Mühendislerin Psikolojik Sözleşme Kapsamında Karşı Taraf Olarak Kimi Algıladıklarına İlişkin Bulgular}

Araştırmaya katılan düşük maaşla istihdam edilen yeni mezun mühendislerin daha çok genel müdürler ile birim yöneticilerini psikolojik sözleşme kapsamında karşı taraf olarak algıladıkları görülmüştür. Bunu sırasıyla insan kaynakları yöneticileri ile işletme müdürleri takip etmektedir. Söz konusu bulgular Tablo 3’te gösterilmiştir.

Tablo 3. Düşük Maaşla İstihdam Edilen Yeni Mezun Mühendislerin Psikolojik Sözleşme Kapsamında Karşı Taraf Olarak Kimi Algıladıklarına İlişkin Bulgular

\begin{tabular}{ll}
\hline $\begin{array}{l}\text { Psikolojik Sözleşmenin Karşı Tarafında İşveren } \\
\text { Olarak Algılanan Kesim }\end{array}$ & Katılımcı Atıfları \\
\hline Genel Müdür & M5, M6, M7, M14, M15 \\
Birim Yöneticisi & M2, M4, M8, M10, M11 \\
İnsan Kaynakları Yöneticisi & M1, M3, M9 \\
İşletme Müdürü & M12, M13 \\
\hline
\end{tabular}

Araştırmaya katılan düşük maaşla istihdam edilen yeni mezun mühendislerin, psikolojik sözleşme kapsamında karşı taraf olarak kimi algıladıklarına ilişkin ifadelerden bazıları aşağıdaki gibidir:

Çalıştı̆̆ım firma kadro olarak çok dallı budaklı olmadığından her konuda direkt genel müdürle görüşüyoruz. Hâl böyle olunca da buradaki durumumla ilgili kafamda şekillenen resimde karşıma hep genel müdürün şekli şemaili geliyor. (M15) 
Benimle ilgili gelişmeleri bire bir gören amirim, çalıştı̆̆ım departmandaki, birimimdeki yöneticim. Bu sebeple ona karşı sorumluluk hissedip işle ilgili, kariyerle ilgili ondan beklenti içinde oluyorum. (M4)

Asgari ücretten hallice para verseler de burası çok kurumsal olarak bilinen bir yer. Oturmuş bir insan kaynaklart sistemi var. Tatmin ediyor ya da etmiyor, ama kurumsal bir insan kaynakları yönetimi var. Bu da bende kurumdan beklentilerimi insan kaynakları müdürü sağlarmış düşüncesi oluşturuyor. (M1)

Işsletme müdürümüz her şeyle ilgilenir. Hep ortalardadır. Derdimizi, sorunumuzu, isteğimizi hep o dinler. Daha iyi olalım diye yol gösterir. Ben de onu abi gibi görürüm. Yaptığım işle ilgili ona karşı utanmak istemem. Beklediğim şeyleri de ona rahatça açık edebilirim. (M12)

Ana araştırma sorusu doğrultusunda, psikolojik sözleşmenin işveren kesimini temsilen çalışma grubuna dâhil edilen yöneticilerin ise psikolojik sözleşme kapsamında karşı taraf olarak kurumlarındaki düşük maaşla istihdam edilen yeni mezun mühendisleri dikkate almaları istenmiştir.

\subsection{Tarafların Psikolojik Sözleşmeye Dair Algılarının Nasıl Oluştuğuna İlişkin Bulgular}

Araştırmaya katılan düşük maaşla istihdam edilen yeni mezun mühendislerin psikolojik sözleşmeye dair algılarının çalışma arkadaşları ile yöneticiler arasındaki ilişkiler üzerinden yaptıkları sosyal gözlemler, işe başvuru sürecinde iletişime geçtikleri kişilerden edindikleri bilgiler, kurumda edindikleri bireysel deneyimler, iş görüşmesi sürecinde yöneticilerle yaşadıkları bireysel deneyimler ve kurumun insan kaynakları politikaları temelinde oluştuğu tespit edilmiştir. Konuya ilişkin bulgular Tablo 4'te sunulmuştur.

Tablo 4. Düşük Maaşla İstihdam Edilen Yeni Mezun Mühendislerin Psikolojik Sözleşmeye Dair Algılarının Nasıl Oluştuğuna İlişkin Bulgular

\begin{tabular}{ll}
\hline $\begin{array}{l}\text { Düşük Maaşla İstihdam Edilen Yeni } \\
\text { Mezun Mühendislerin Psikolojik } \\
\text { Sözleşmeye Dair Algılarının Oluşumunda } \\
\text { Etkili Olan Faktörler }\end{array}$ & Katılımcı Atıfları \\
\hline $\begin{array}{l}\text { Çalışma arkadaşları ile yöneticiler arasındaki } \\
\text { ilişkiler üzerinden yapılan sosyal gözlemler }\end{array}$ & M2, M4, M5, M6, M7, M8, M11, M12, M13, M14, \\
\hline $\begin{array}{l}\text { İşe başvuru sürecinde iletişime geçilen } \\
\text { kişilerden edinilen bilgiler }\end{array}$ & M5, M6, M7, M11, M12, M13, M14, M15 \\
\hline Kurumda edinilen bireysel deneyimler & M1, M2, M3, M4, M8, M9, M10, M11 \\
\hline $\begin{array}{l}\text { İş görüşmesi sürecinde yöneticilerle yaşanılan } \\
\text { bireysel deneyimler }\end{array}$ & M1, M2, M3, M4, M9, M10, M11 \\
\hline Kurumun insan kaynakları politikaları & M1, M2, M3, M4, M9, M10, M11 \\
\hline
\end{tabular}

Araştırmaya katılan düşük maaşla istihdam edilen yeni mezun mühendislerin psikolojik sözleşmeye dair algılarının nasıl oluştuğuna ilişkin ifadelerden bazıları aşağıda verilmiştir:

Ben şu anda çalıştığım bu firmaya başvurmadan önce burada çalışan üniversiteden sınıf arkadaşımla konuşmuştum. Ortamın nasıl olduğunu, şartların nasıl olduğunu, üstlerin nasıl olduğunu, çalışanların nasıl olduğunu gibi gibi o da anlatmıştı, ben de sormuştum. Birim amirim ile yaptığım yüz yüze iş görüşmesinde de öyle ya da böyle birtakım beklentiler ve sorumlulukların lafi geçmiş oldu. E işletmenin maaşı, mesaisi gibi şeyler, prosedürler var duyulan. Sonra işe başlayınca ortama bakıp kafandan bir şeyler geçiriyorsun. E kendi yaşadıkların oluyor gibi gibi bir bakmışsın kafanda bir sürü şey dönüyor. Şunu yaparsam 180 
şöyle olur. Bunu yaparsam böyle olur. Ama şunda şöyle olmuştu gibi gibi sürekli dolaşıyor tilkiler. (M11)

Aldıklarım-verdiklerim, alacaklarım-vereceklerim muhasebesinde; şirketin insan kaynakları politikaları ile yöneticinin bunları nasıl verdiğini, kendi başımdan geçenler ve diğerlerinin başından geçenlerle karşılaştırıp değerlendiriyorum. (M2)

Ben büyük, kurumsal bir firmada çalışıyorum. Zaten o yüzden bir personelin işyerinden bekleyeceği tüm şeyler bir sistem içinde sunulmuş vaziyette. Nasıl derseniz? İnsan kaynaklarl sistemleri var, iş görüşmesinde süreç içinde hep insan kaynaklarcılar var. Çalışırken yaptıkların ya da yapmadıkların ya da yapamadıkların için de hep insan kaynakları devrede. Böylelikle işe karşı, kariyerine karşı zihninde oluşan düşüncelerde bununla ilgili tecrübelerin ön planda oluyor. (M9)

Şimdi bizde bir elalemcilik var ya; hani o n'apmış, bu n'apmış, nasıl yapmışlar? Hıh işte bunda da böyle oluyor bence. Senden önce oraya işe giren var mi ilk ona bakıyorsun, bir sorup soruşturuyorsun ve kafanda ölçüp tartıp hayallere dallyorsun. Sonra işe girdiğinde de n'olup ne bittiğini kıyaslayıp duruyorsun. Firma zaten küçük, ortam buna elverişli. Ahmet'e şunu yaptılar, bana da öyle olur gibi direkt bir beklenti içine giriyorsun. (M6)

Araştırmaya katılan yöneticilerin psikolojik sözleşmeye dair algılarının ise personelle iş görüşmesi sürecinde yaşanılan bireysel deneyimler, personelin kurumdaki olumsuz koşullar karşısında sergilediği tutum ve davranışlar, personele ilişkin referans değerlendirmeleri, personelin çalışma arkadaşları ödüllendirildiği zaman sergilediği tutum ve davranışlar ile personelin iş disiplini temelinde oluştuğu saptanmıştır. Söz konusu bulgular Tablo 5'te gösterilmiştir.

Tablo 5. Yöneticilerin Psikolojik Sözleşmeye Dair Algılarının Nasıll Oluştuğuna İlişkin Bulgular Yöneticilerin Psikolojik Sözleşmeye Dair Katılımcı Atıfları Algılarının Oluşumunda Etkili Olan

Faktörler

Personelle iş görüşmesi sürecinde yaşanılan $\quad$ Y1, Y2, Y3, Y4, Y5, Y6, Y7, Y8, Y9, Y10, Y11

bireysel deneyimler

Personelin kurumdaki olumsuz koşullar $\quad$ Y2, Y4, Y5, Y6, Y8, Y9, Y10, Y11

karşısında sergilediği tutum ve davranışlar

Personele ilişkin referans değerlendirmeleri $\quad$ Y1, Y3, Y5, Y7, Y9, Y10, Y11

Personelin çalışma arkadaşları $\quad \mathrm{Y} 2, \mathrm{Y} 3, \mathrm{Y} 4, \mathrm{Y} 8, \mathrm{Y} 9$

ödüllendirildiği zaman sergilediği tutum ve

davranışlar

Personelin iş disiplini $\quad$ Y2, Y4, Y6, Y8, Y9

Araştırmaya katılan yöneticilerin psikolojik sözleşmeye dair algılarının nasıl oluştuğuna ilişkin ifadelerden bazıları aşağıda sunulmuştur:

Aslında çoğu zaman o çalışanı kimin önerdiği, ona kefil olanın bendeki kredisine göre onun nasıl işler çıkarabileceği bende şekillenmeye başlıyor. Sonra iş görüşmesinde karşılıklı oturup konuştuğumuzdaki şeylerde, sonradan çalışmaya başladı̆̆ındaki hâllerini de gördügümde çok da yanılmadı̆̆ımı görüyorum... Ha bir de şöyle durumlar oluyor: Sıkıcı prosedürler, ekstra yükler gibi durumlarda ne yaptı̆̆ da kafamda onunla ilgili geleceği resmediyor. Ya da rakip gördüğ̈̈ akranı terfi aldı̆̆ında bize küsüyor mu, şevke gelip daha mı çok çalışıyor bunlar hep ipucu. (Y9) 
Departmanımdaki yeni mezun mühendislerin iş yapışını, prosedürlere uyumunu, işletme içindeki ilişkilerini, gelecek mesleki hedeflerini takip etmeye çalışlyorum. Buralardan aldı̆̆ım doneler, zihnimdeki onlarla ilgili düşünceleri geliştiriyor. İlişkisel bazda da arkadaşlarını takdir ettiğime şahit olduklarında, bu onlara nasıl yanslyor diye de baklyorum. Kıskanıyor $m u$, düşman mı oluyor, motive mi oluyor bu strada rengini belli ediyor bence. (Y4)

Genel müdür olarak işe alımlarda bizzat rol alıyorum. Artık zamanla biraz da insan sarrafi olduk diyebiliriz. O nedenle de ta iş görüşmesinde notunu veririm çoğu zaman. Kişiye aracı olan hatırı sayllır, sözüne güvenilir de bir ahbabımız var ise de bize şunlart şunlarl verir, gelsin çalışsın diyoruz. Tabi elemanı denediğimiz anlar da var, misal; işler sıkıştı veya angarya bir şey çıktı. Hıh işte o zaman n'apar onu iyi ölçmek lazım. (Y5)

Bir insan kaynakları yöneticisi olarak bizler çoğunlukla iş görüşmelerinde herhâlde bu tür algısal değerlendirmelerimizi oluşturuyoruz. Bir adım ötesinde de adayın referans araştırması aşamasında edindiğimiz doğru bilgilerle pekiştiriyoruz. Hatta adayın ismi içeriden cevval bir çalışandan gelmişse bizim için performans sonuçları çok da şaşırtıcı olmuyor, eğer çok elzem bir case yaşamamışsak. (Y7)

\subsection{Tarafların Psikolojik Sözleşme Kapsamında Birbirlerinden Ne Beklediklerine İlişkin Bulgular}

Araştırmaya katılan düşük maaşla istihdam edilen yeni mezun mühendislerin psikolojik sözleşme kapsamında yöneticilerinden beklentilerinin Tablo 6'da verildiği gibi değer, sayg1 ve takdir görmek, gelişim olanaklarına sahip olmak, daha fazla sorumluluk ve inisiyatif almak, daha iyi çalışma koşullarına sahip olmak, iş-özel yaşam dengesi sağlamak, esnek ödül paketi ve örgütsel adalet olduğu belirlenmiştir.

Tablo 6. Düşük Maaşla İstihdam Edilen Yeni Mezun Mühendislerin Psikolojik Sözleşme Kapsamında Yöneticilerinden Ne Beklediklerine İlişkin Bulgular

\begin{tabular}{ll}
\hline $\begin{array}{l}\text { Düşük Maaşla İstihdam Edilen Yeni } \\
\text { Mezun Mühendislerin Psikolojik Sözleşme } \\
\text { Kapsamında Yöneticilerinden Beklentileri }\end{array}$ & Katılımcı Atıfları \\
\hline Değer, sayg1 ve takdir görmek & M1, M2, M3, M4, M5, M6, M7, M8, M9, M10, \\
& M11, M12, M13, M14, M15 \\
\hline Gelişim olanaklarına sahip olmak & M2, M4, M5, M6, M7, M8, M10, M12, M13, M14, \\
& M15 \\
\hline Daha fazla sorumluluk ve inisiyatif almak & M2, M4, M5, M6, M8, M10, M12, M13, M14, \\
& M15 \\
\hline Daha iyi çalışma koşullarına sahip olmak & M2, M4, M6, M7, M8, M10, M13, M14, M15 \\
\hline İs-özel yaşam dengesi sağlamak & M1, M2, M3, M6, M7, M8, M12, M14 \\
\hline Esnek ödül paketi & M1, M2, M3, M4, M9, M10, M11 \\
\hline Örgütsel adalet & M2, M4, M9, M10 \\
\hline
\end{tabular}

Araştırmaya katılan düşük maaşla istihdam edilen yeni mezun mühendislerin psikolojik sözleşme kapsamında yöneticilerinden ne beklediklerine ilişkin ifadelerden bazıları aşağıdaki gibidir:

Eğitim sisteminin ceremesini çektiğimizi düşünüyorum. Okulda ögrrendiklerimizin ezber ve çöp olduğu, asl ögrenme yerinin iş hayatı olduğu vuruluyor yüzümüze hep. O yüzden yeni mezunsun, deneyimsizsin, ben sana iş ögreteceğim ve bir de üstüne para vermem gerekecek bari minimumda vereyim sisteminin bir parçası olmak durumunda kalıyoruz. Bu hâlimizle işe 
alınmamız bir lütuf gibi sunuluyor. Bu tablo da insana değersiz hissettiriyor. Oysaki öyle ya da böyle büyük bir emek var. Iyi hissetmek istiyor insan. Çabası görülsün, bilinsin, duyulsun istiyor. Çaylak muamelesi kısa sürsün istiyor. İyi iş çıkardın, çok çalıştığının farkındayım, şu aşamada gayretinin karşılığını iyi bir ücretle taçlandıramıyor olsak da potansiyeline saygı duyuyoruz gibi takdir, teşekkür içerikli dönütler almak istiyor. (M3)

Laf aramızda benim için burası bir atlama taşı. Sektörü çözeyim, işi öğreneyim, çevre edineyim kendi ofisimi açacağım. Ama özgüvenimin gelmesi lazım önce, daha zamanı var yani. Burada stajyer muamelesi görmek üzüyor. Saygl duyulmuyor. Neden? Çünkü sen daha çok gençsin, onlar ise hayat tecrübesi ile dolu! Hani klasiktir ya, hayat üniversitesinden mezun olanlar derneği... Onlar tırnaklarıyla kazımışlardır, altın tepside sunulmamıştır hiçbir şey. Senin daha bir firın ekmek yemen lazımdır. Sen giderken, onlar dönüyordur. Isşte böyle bir ortam benim kendime saygıma iyi gelmiyor. Dĕgersiz değilim ki ben. (M13)

Ülkemizde deneyim çok çok önemli sektör için. İş piyasası da çok çok sıkıntıll. Bu yüzden yeni mezunken bir an önce bir işe girmeye, işsiz kalmamaya bakıyorsun. Girdiğin işte de yıllarca aynı seviyede kalmak istemiyorsun. Deneyim kazandıkça, bir şeyler ögrendikçe yükselmeyi bekliyorsun. (M5)

Zaten yeni mezun amatörlüğü için önyargılı yaklaşıllyor, e madem bunu aşmama destek olunsun. Eğitimler să̆lansın. Yüksek lisans yapmam için zaman să̆lansın. (M4)

Işsle ilgili otoritem olsun isterim. Yani bana güvensin, fikirlerimi dikkate alsın, topa girmeme izin versin, bir şeyleri halletmek için onu beklemek zorunda olmayayım. En iyi, en basit yolunu bilir zaten desin. (M14)

Mesai bitiminde tek başına bir şeyler çözdüğünü bilmek güzel bir duygu. Bunun için özgür bir alan sunulması çok klymetli. İş bitirme, işi çözme yetkisi. Böyle bir güç verilsin. (M8)

Gerçek mühendis maaşına ulaşmak. Sonuçta asgari ücret gibi bir miktara talim etme hayaliyle okumuyoruz hiçbirimiz. Aylık sabit masraflarımdan fazlasını kazanmak. İyi bir destek paketi almak... Benden ne beklendiği konusunda netlik, sorumluluk alanlarımızın belli olması... Zamanının çoğunu geçirdiğin ortamın mutlu olması. Mesai arkadaşlarımla, amirlerimle iyi bir iletişim ortamı olması. Yardımlaşma, işbirliği, destek ortamı. Mobbing'den uzak bir ortam. Güven ortamı, huzur ortamı, rahat iletişim ortamı. Mesela yapmaktan mutlu olmadı̆̆ım bir şey olduğunda, direkt yöneticimle samimiyetle konuşabilmeliyim. Sadece ben değil, hepimiz. Yönetici bu eşit duruşu gösterebilmeli. (M10)

Çalışma saatlerinin uyarlanabilir olması, kendimle ilgili bir işim olduğunda rahatça izin alabilmem önemli bence bu zamanda. Iş̧im bittiğinde çıkabilmeliyim örneğin. Keşke iş için ömrümüzün çoğu anı gitmese, kendimiz için de bol bol, doyasıya anlar, zamanlar kalsa. Belki yetişme telaşemiz en aza iner böylelikle. Koşturmaca stresim biter. (M7)

Dediğim gibi kurumsal bir işletmedeyim ben, yürüyen bir sistem var. Ama mesaiye kalma fikri ya da hafta sonu sürprizleri, denetim zamanlarındaki emir eri durumlar zaman zaman can sıkıcı bir hâl almıyor değil tabi. Yani bana cumartesi için nöbet çıkarmış olabilir, ama benim işim varsa ayarlanabilmeli. Biz n'apıyoruz, kendi aramızda arkadaşlarla değişim sağlamak için uğraşıyoruz. Ama üstüne bir de idareden bunun iznini, onayını almak için uğraşıp kıvranıyoruz. Bu kadar katı olmamall, nefes alabilmeliyim ben. Yoksa n'oluyor, o cumartesi yapacaklarımda kalıyor aklım. Böylece zaten işe tam konsantre olamıyorum. Sabotaj fikrileri doluyor kafama ister istemez. Dengeli, esnek bir tarz daha gerginlikten uzak ve motive edici... 
Bir de servis, yemek gibi haklar temel seviyeye dâhil olsa ve bonuslar bireysel seçimlere göre verilse çok daha mutlu olurdum. Mesela ihtiyaçlarımı sorulsa ve performansımıza göre paketler sunulsa; yurtdışı eğitimi, tatili, sinema üyeliği. Yani standart bayram bonusu, emeklilik yardımı güncellense. Yani genç ve bekâr birinin tercihleri ile orta yaşlardaki evli ve çocuklunun geçim derdinin farkı dikkate alınsa. (M1)

Yöneticimden adil olmasını beklerim. İşleri dă̆ıtırken, performans değerlendirirken bu eşitlik önemli. Aynı seviyedeki hepimize aynı mesafede yaklaşması önemli. Sonuçta herkes pastadan en büyük payı almanın derdinde. Adaletli muamele kritik husus. (M2)

Biri yöneticime benimle ilgili olumsuz bir şey söylediğinde, odaya beni de çă̆ırmasını beklerim. Böylece olayı tek taraflı dinlememiş olur. İkimize de eşit durmuş olur. Baktı̆̆ında zaten olmasi gereken de budur. (M9)

Araştırmaya katılan yöneticilerin psikolojik sözleşme kapsamında kurumlarındaki düşük maaşla istihdam edilen yeni mezun mühendislerden beklentilerinin ise Tablo 7'de verildiği gibi iş disiplini, çalışkanlık ve özveri, örgütsel çıkarların gözetilmesi, örgütsel bağlılık, dürüstlük ve güvenilirlik ile gelişime açık olunması olduğu belirlenmiştir.

Tablo 7. Yöneticilerin Psikolojik Sözleşme Kapsamında Kurumlarındaki Düşük Maaşla İstihdam Edilen Yeni Mezun Mühendislerden Ne Beklediklerine İlişkin Bulgular

\begin{tabular}{ll}
\hline $\begin{array}{l}\text { Yöneticilerin Psikolojik Sözleşme Kapsamında } \\
\text { Kurumlarındaki Düşük Maşla İstihdam } \\
\text { Edilen Yeni Mezun Mühendislerden } \\
\text { Beklentileri }\end{array}$ & Katılımcı Atıfları \\
\hline İş disiplini, çalışkanlık ve özveri & \\
\hline & Y1, Y2, Y3, Y4, Y5, Y6, Y7, Y8, Y9, Y10, \\
\hline Örgütsel çıkarların gözetilmesi & Y11 \\
\hline Örgütsel bağlılık & Y1, Y3, Y5, Y7, Y9, Y10, Y11 \\
\hline Dürüstlük ve güvenilirlik & Y5, Y9, Y10, Y11 \\
\hline Gelişime açı olunması & Y3, Y10, Y11 \\
\hline
\end{tabular}

Araştırmaya katılan yöneticilerin psikolojik sözleşme kapsamında kurumlarındaki düşük maaşla istihdam edilen yeni mezun mühendislerden ne beklediklerine ilişkin ifadelerden bazıları aşağıdaki gibidir:

Çalışmaya heves, tembel olmaması, üşenmemesi, işten erinmemesi. Sorsun, araştırsın, ögrensin. Yük görmesin yeni şeylerin takipçisi olmayl. Bizi büyütmeye gayretli olması. Pek sabırlı değil şimdiki gençler. Bir an önce fazlasını istiyorlar. Biz büyüdükçe, onu da orada bırakmayacağımızı bilerek sabırla işine asılması. 500 lira fazla veriyor diye rakip firmaya geçmemesi. Güven olsun. Aile gibi olalım. Zor zamanlarda gemiyi kimse terk edip gitmesin. Ama tabi yeni neslin turnover oranlarl da ortada maalesef. Sebat etmiyorlar. (Y11)

Işsinin takipçisi olsun. Sıkı çalışsın. Girişken olsun. Biraz daha fazlasını yapmayı denesin. Değişmeye, gelişmeye hazır olsun. Mert olsun. Para kazandı̆̆ yeri sahiplensin, kollasın. Gözü dışarda olmasın. Sadakat göstermesi önemlidir yani. (Y10)

Ikkili oynanmamasını beklerim. Dürüst olmasını beklerim. Özenli çalışılması, nitelikli iş çıkarılması, yüksek performans gayreti gösterilmesi, işletme kurallarına riayet edilmesi, giriş-çıkış-mola saatlerinde titizlik, kuruma karşı-yaptı̆̆ işe karşı vicdani sorumluluk 
taşıması, sabote etmemesi, çalışma arkadaşlarına karşı yardımsever olması. Tabi bir de genelde sorun yaşadığımız fazla mesai konusunda uyumlu olması gibi hususlar yani. (Y3)

Personelin iş tanımının ötesine geçebilmesi, bundan gocunmaması önemli bir faktör. Kaytarmaması, şirket politikalarına bağlı kalması, elinden geleni esirgediğinde hep birlikte zarar göreceğimizin bilincinde olmast. (Y1)

\subsection{Tarafların Psikolojik Sözleşme Kapsamında Karşı Tarafın Kendilerinden Ne Beklediğini Düşündüklerine İlişkin Bulgular}

Araştırmaya katılan düşük maaşla istihdam edilen yeni mezun mühendislerin psikolojik sözleşme kapsamında yöneticilerinin kendilerinden beklentilerinin çalışkanlık, örgütsel kurallara uygun davranılması, dürüstlük ve örgütsel bağlılık olduğunu düşündükleri tespit edilmiştir. Söz konusu bulgular Tablo 8'de sunulmuştur.

Tablo 8. Düşük Maaşla İstihdam Edilen Yeni Mezun Mühendislerin Psikolojik Sözleşme Kapsamında Yöneticilerinin Kendilerinden Ne Beklediklerini Düşündüklerine İlişsin Bulgular

Düşük Maaşla İstihdam Edilen Yeni Katılımcı Atıfları

Mezun Mühendislerin Psikolojik

Sözleşme Kapsamında Yöneticilerinin

Kendilerinden Beklentilerine Dair

Algiları

Çalışkanlık M1, M2, M3, M4, M5, M6, M7, M8, M9, M10, M11, M12, M13, M14, M15

\begin{tabular}{ll}
\hline Örgütsel kurallara uygun davranılmas1 & M1, M3, M5, M6, M7, M9, M12, M13, M14, M15 \\
\hline Dürüstlük & M2, M3, M6, M8, M11, M13, M14, M15 \\
\hline Örgütsel Bağl1lık & M5, M6, M7, M12, M13, M14, M15 \\
\hline
\end{tabular}

Araştırmaya katılan düşük maaşla istihdam edilen yeni mezun mühendislerin psikolojik sözleşme kapsamında yöneticilerinin kendilerinden beklentilerine dair algılarına ilişkin örnek ifadeler aşağıda verilmiştir:

Işsimi yapayım, işimi vaktinde bitireyim, çok çalışayım ister. İşe zamanında geleyim ister. Sayg ister. Insanlar birbiriyle iyi geçinsin ister. Huzuru bozmayayım, söylenenleri yapayım, kuralları çiğnemeyeyim ister. Başka iş aramayayım, ama çok da para vermesin ister. Patron kafası böyle. İşi ögren, ucuza çalış, hep bana fayda sağla. Güven ver, işi öğrenip kaçma. Arkamdan iş çevirme istiyorlar. (M6)

Yöneticiler genelde sadık görev insanlarını çok severler. İşini yap, pek sesini çıkarma. Prosedürlere karşı gelme. Açık ol, alavere dalavere peşinde olma. İ̧̧i öğrenip çalışmaya devam edenleri tercih ederler. (M13)

Yönetim benden ne bekler, en başta iş odaklılık bekler. Sıkı çalışmamı bekler. Sonra sorun çıkarmamamı, düzene uymamı bekler. Doğru davranmamı bekler. Hata yaptığımda açıkça söylememi bekler. Illk sırada aklıma gelenler bu şekilde. (M3)

İş öğrenelim, çalışalım. Müşteri memnun olsun, şirket para kazansın. Hep çalışalım, çok çalışalım. İyi çalışan olalım. Nitelikli iş çıkaralım. İş ahlakımız olsun. Doğru dürüst çalışalım. Böyle şeyler bence. (M8)

Araştırmaya katılan yöneticilerin psikolojik sözleşme kapsamında kurumlarındaki düşük maaşla istihdam edilen yeni mezun mühendislerin kendilerinden beklentilerinin ise daha iyi çalışma koşullarına sahip olmak, esnek çalışma saatleri, daha fazla sorumluluk ve inisiyatif 
almak ve gelişim olanaklarına sahip olmak olduğunu düşündükleri tespit edilmiştir. Söz konusu bulgular Tablo 9'da sunulmuştur.

Tablo 9. Yöneticilerin Psikolojik Sözleşme Kapsamında Kurumlarındaki Düşük Maaşla İstihdam Edilen Yeni Mezun Mühendislerin Kendilerinden Ne Beklediklerini Düşündüklerine İlişkin Bulgular

\begin{tabular}{ll}
\hline $\begin{array}{l}\text { Yöneticilerin Psikolojik Sözleşme Kapsamında } \\
\text { Kurumlarındaki Düşük Maaşla İstihdam } \\
\text { Edilen Yeni Mezun Mühendislerin } \\
\text { Kendilerinden Beklentilerine Dair Algıları }\end{array}$ & Katılımcı Atıfları \\
\hline Daha iyi çalışma koşullarına sahip olmak & Y1, Y2, Y3, Y4, Y5, Y6, Y7, Y8, Y9, Y10, \\
& Y11 \\
\hline Esnek çalışma saatleri & Y2, Y3, Y5, Y6, Y7, Y8, Y9, Y11 \\
\hline Daha fazla sorumluluk ve inisiyatif almak & Y1, Y2, Y3, Y6, Y7, Y8, Y10 \\
\hline Gelişim olanaklarına sahip olmak & Y2, Y3, Y4, Y6, Y8 \\
\hline
\end{tabular}

Araştırmaya katılan yöneticilerin psikolojik sözleşme kapsamında kurumlarındaki düşük maaşla istihdam edilen yeni mezun mühendislerin kendilerinden beklentilerine dair algılarına ilişkin örnek ifadeler aşağıda verilmiştir:

Deneyimsiz yeni mezunları temel başlangıç ücreti pek tatmin etmez çoğunlukla. Bu nedenle öncelikle daha yüksek bir ücret beklentisi vardır. Bir de şimdi gençler iyi iletişimli çalışma ortamında daha motiveler. Teknolojinin getirdiği, sosyal medyanın getirdiği, oyun çağının getirdiği bir beklenti diye düşünüyorum. Ë̆lenceli ortam istiyorlar. Çalışırken daha özgür olmak istiyorlar. Mesai mefhumu çoğunlukla canlarını sılkyor. Iş bitince raporlama yapmak zül geliyor. Bir de çok aceleciler. Hemen daha fazlasını isteyebiliyorlar. Biz onlara eğitimler sunalım, hemen terfiler verelim. Çabucak yükselsinler ve doğru orantıl olarak koşulları iyileşsin. (Y2)

Para temel itici güçtür. Ana beklenti kesinlikle paradır, çok paradır. Ulaşım, sağlık sigortası, yemek çeki gibi yan destekler de iyi olsun istenir. Iyi bir ofis ortami. Son model ekipmanlar. Uzun süre aynı pozisyonda da kalmak istenmez. Bunu sağlamak için destek beklenir. Eğitimse ĕgitim, kurssa kurs. Daha başka ne var, ne var? İşimi yaptıktan sonra istediğim saatte gelip gideyim kafasi da var ekstra. Ama en temeli para bence. (Y6)

Düşük maaşla çalışan yeni mezun mühendisler işletmeden öncelikle ne bekler? Kesinlikle yüksek maaş bekler. Şirket aracı verilsin ister. Yüksek lisans yapmak için izin ister. Durum idare edilsin, fazla mesai yapmasin ister. Duruma göre sabah erken gelmesin, akşam geç çıkmasın. Yüksek lisansı bitirirse de tebrik bekler, terfi ister. (Y8)

Kuşaklar değişiyor. Eskinin kanaatkârlı̆̆ pek yok artık şimdikilerde. Hep daha iyisi, daha fazlası peşindeler gençler çoğu zaman. Bu eğilim de işyerlerine de otomatikman yanslyor. Daha iyi iş, daha iyi ilişki, daha destekleyici yönetim, daha geliştirici ortam, daha iyi ĕ̌itim, daha iyi destek. (Y4)

\section{SONUÇ, TARTIŞMA VE ÖNERILER}

Bu araştırmada, düşük maaşla istihdam edilen yeni mezun mühendislerin psikolojik sözleşme kapsamında karşı taraf olarak kimi algıladıkları, tarafların psikolojik sözleşmeye dair algılarının nasıl oluştuğu ve psikolojik sözleşme kapsamındaki karşılıklı beklenti ve yükümlülüklere ilişkin düşük maaşla istihdam edilen yeni mezun mühendisler ile 
yöneticilerinin bakış açıları nitel bir yaklaşımla irdelenmiştir. Yapılan fenomenolojik analiz sonucunda elde edilen bulgular, toplanan verilerin doğasına sadık kalınarak katılımcı ifadelerinden doğrudan alıntılarla ortaya konulmuştur. Sonuçta, psikolojik sözleşmenin oluşumu ve kapsamına ilişkin düşük maaşla istihdam edilen yeni mezun mühendisler ile yöneticilerinin işlemsel ve ilişkisel temelde farklı algılara sahip olduğu tespit edilmiştir. Araştırmanın sonuçlarına yönelik tümevarıma dayalı bir anlayış çerçevesinde ve analitik genelleme temelinde mevcut yazındaki konuya ilişkin diğer çalışmaların tespitleriyle karşılaştırmalı olarak gerçekleştirilen kuramsal değerlendirme aşağıda detaylı bir biçimde sunulmuştur:

- Araştırmaya katılan düşük maaşla istihdam edilen yeni mezun mühendislerin daha çok genel müdürler ile birim yöneticilerini psikolojik sözleşme kapsamında karşı taraf olarak algıladıkları görülmüştür. Bunu sırasıyla insan kaynakları yöneticileri ile işletme müdürleri takip etmektedir. Söz konusu bulgu, katılımcıların algılarının hangi bağlamsal koşullarda ve nasıl biçimlendiği temelinde değerlendirildiğinde; patron sahipliğindeki görece olarak daha küçük işletmelerde genel müdür ve işletme müdürü pozisyonundaki yöneticilerin tüm kurumsal süreçlerle doğrudan ilgili olmaları nedeniyle çalışanların psikolojik sözleşmenin karşı tarafına onları konumlandırdıkları ifade edilebilir. İlgili departman amirlerini temsil eden birim yöneticilerinin ise daha çok işle ilgili faktörlerin yakın takipçisi olmaları nedeniyle çalışanlar tarafından psikolojik sözleşmenin karşı tarafına konumlandırıldıkları söylenebilir. Daha kurumsal bir yapıya sahip olan ve insan kaynakları departmanı bulunan işletmelerde ise çalışanların istihdama ilişkin algısal beklentileri temelinde psikolojik sözleşmenin karşı tarafına insan kaynakları yöneticilerini konumlandırdıkları belirtilebilir. Bu bulgu, Herriot ve arkadaşlarının (1997: 151), hat yöneticisi ya da insan kaynakları yöneticisi gibi örgütün farklı temsilcilerinin beklentiler ve yükümlülükler hakkında farklı mesajlar gönderebileceği yönündeki iddiaları ile örtüşmektedir. Ayrıca örgütlerin bir psikolojik sözleşmeye sahip olmamakla birlikte, yöneticilerin psikolojik sözleşme kapsamında örgütün bir temsilcisi sayıldığının altı çizilmektedir (McDermott vd., 2013; Rousseau ve Greller, 1994; Rousseau, 2001; Shore ve Tetrick, 1994).

- Araştırmaya katılan düşük maaşla istihdam edilen yeni mezun mühendislerin psikolojik sözleşmeye dair algılarının çalışma arkadaşları ile yöneticiler arasındaki ilişkiler üzerinden yaptıkları sosyal gözlemler, işe başvuru sürecinde iletişime geçtikleri kişilerden edindikleri bilgiler, kurumda edindikleri bireysel deneyimler, iş görüşmesi sürecinde yöneticilerle yaşadıkları bireysel deneyimler ve kurumun insan kaynakları politikaları temelinde oluştuğu tespit edilmiştir. Diğer taraftan araştırmaya katılan yöneticilerin psikolojik sözleşmeye dair algılarının ise personelle iş görüşmesi sürecinde yaşanılan bireysel deneyimler, personelin kurumdaki olumsuz koşullar karşısında sergilediği tutum ve davranışlar, personele ilişkin referans değerlendirmeleri, personelin çalışma arkadaşları ödüllendirildiği zaman sergilediği tutum ve davranışlar ile personelin iş disiplini temelinde oluştuğu saptanmıştır. Söz konusu bulgu, Freese ve Schalk (1996) ile Rousseau ve Greller'in (1994), psikolojik sözleşme kapsamındaki beklentilerin etkileşim, gözlem, işe alım ve insan kaynakları uygulamaları aracılığıyla biçimlendiğine ilişkin açıklamalarıyla tutarlıdır. Yönetici bakış açısına odaklanıldığında ise Randmann (2013), yöneticiler için psikolojik sözleşmenin davranışlar ve gözlemler yoluyla oluştuğunu 
belirtmektedir. Sherman ve Morley (2015) de yöneticilerin psikolojik sözleşmelerinin oluşumunda eski çalışanlarına ilişkin geçmiş tecrübelerinin olumsuz etkilerinin olduğuna işaret etmektedirler. Ayrıca çalışanların işe başvuru sürecinde iletişime geçtikleri kişilerden edindikleri bilgiler ile yöneticilerin personele ilişkin referans değerlendirmeleri temelinde oluşan psikolojik sözleşme algıları üzerinde Türk kültürünün, Hofstede (1980) tarafindan ortaya koyulan ulusal kültür boyutlarına göre toplulukçu ve ilişki yönelimli özelliklerinin etkileri hissedilmektedir.

- Araştırmaya katılan düşük maaşla istihdam edilen yeni mezun mühendislerin psikolojik sözleşme kapsamında yöneticilerinden beklentilerinin değer, saygı ve takdir görmek, gelişim olanaklarına sahip olmak, daha fazla sorumluluk ve inisiyatif almak, daha iyi çalışma koşullarına sahip olmak, iş-özel yaşam dengesi sağlamak, esnek ödül paketi ve örgütsel adalet olduğu belirlenmiştir. Diğer taraftan araştırmaya katılan yöneticilerin psikolojik sözleşme kapsamında kurumlarındaki düşük maaşla istihdam edilen yeni mezun mühendislerin kendilerinden beklentilerinin ise daha iyi çalışma koşullarına sahip olmak, esnek çalışma saatleri, daha fazla sorumluluk ve inisiyatif almak ve gelişim olanaklarına sahip olmak olduğunu düşündükleri tespit edilmiştir. Bu noktada, çalışanlar tarafında daha çok duygusal ve manevi beklentiler temelinde oluşan ilişkisel sözleşmelerin öne çıkmasına rağmen; yöneticilerin bu yöndeki algılarında maddi ve ekonomik beklentiler temelinde oluşan işlemsel sözleşmelerin öne çıktığı görülmektedir. Bu bulgu, Akar (2017a, 2017b) ve Möller'in (2014) araştırma sonuçlarıyla desteklenmektedir. Bu kapsamda, Akar'ın (2017a) mavi yakalı çalş̧anlarla gerçekleştirdiği araştırmada, söz konusu katılımcıların psikolojik sözleşmeye dair algılarının içeriğinde işyerinde değer görme beklentilerinin öne çıktığı saptanmıştır. Yine Akar'ın (2017b) konuya ilişkin diğer bir araştırmasında da işverenlerin, mavi yakalı çalışanların psikolojik sözleşme kapsamında ücret, yan ödemeler, esnek vardiya ve izin planlaması gibi beklentilere sahip oldukları algısı taşımalarına rağmen; mavi yakalı çalışanların ise değer görme, takdir edilme, mesleki gelişim imkânı ve uzun dönemli istihdam güvencesi gibi beklentilere sahip oldukları görülmüştür. Möller (2014) de yöneticilerin, alt kademe çalışanları için paranın psikolojik sözleşmenin ardındaki ana beklenti ve itici faktör olduğu varsayımlarının, ulaştı̆̆ı bulgular ile çürütüldüğünü belirtmiştir.

- Araştırmaya katılan yöneticilerin psikolojik sözleşme kapsamında kurumlarındaki düşük maaşla istihdam edilen yeni mezun mühendislerden beklentilerinin iş disiplini, çalışkanlık ve özveri, örgütsel çıkarların gözetilmesi, örgütsel bağlılık, dürüstlük ve güvenilirlik ile gelişime açık olunması olduğu saptanmıştır. Diğer taraftan araştırmaya katılan düşük maaşla istihdam edilen yeni mezun mühendislerin psikolojik sözleşme kapsamında yöneticilerinin kendilerinden beklentilerinin ise çalışkanlık, örgütsel kurallara uygun davranılması, dürüstlük ve örgütsel bağl1lık olduğunu düşündükleri belirlenmiştir. Bu noktada, yöneticilerin iş, performans ve kurumsal çıkarlar odaklı önceliklere sahip olmaları hususunda çalışanların da hemfikir olduğu söylenebilir. Psikolojik sözleşme kapsamının, karşlıklılık ilkesi temelinde istihdam ilişkisinin her iki tarafı açısından da ele alınmasının önemine dikkat çeken Coyle-Shapiro ve Kessler'in (2002: 76) çalışmasında da çalışan yükümlülükleri arasında gerektiğinde fazla mesai yapılması, işin bir parçası olmayan görevlerin yapılması hususunda gönüllü olunması, nasıl daha iyi iş çıkarılabileceğinin yollarının aranması, çalışma alanında işlerin yapılma şeklinin 
nasıl geliştirilebileceğinin yollarının aranması, işin bir parçası olarak yapılanlar konusunda esnek olunması, çalışma saatleri hususunda esnek olunması, bir görevi bitirmek için ücretsiz olarak fazla mesai yapılması, maliyetleri düşürmenin yollarının aranması ve işin yapılma şeklindeki değişikliklere uyum sağlanması yer almaktadır. $\mathrm{Bu}$ bağlamda, yöneticilerin çalışanlarla kurdukları psikolojik sözleşmelerin zemininde yönetimci bakış açısının yattığı anlaşıımaktadır. Yönetimci yaklaşım; geliştirilen ve meşrulaştırılan yönetsel kontrol araçlarıyla aslında kapitalizmin nihai amacına hizmet etmekte, diğer bir ifadeyle verimliliğin ve dolayısıyla kârın daha fazla artırılmasına odaklanmakta ve çalışanı amaç olarak öne çıkarmak niyeti taşımamakta, aksine istihdam ilişkisinde değer yargılarının önemini göz ardı ederek çalışanı araç olarak kullanmaktadır. Bu çerçevede, özellikle insan kaynakları yönetimi uygulamaları aracılığıly örgütsel performansın artırılmasına yönelik baskıcı tutum kamufle edilerek, çalışanların örgütsel hedefler için kendiliğinden çaba göstermeleri sağlanmaktadır. Böylece aslında yönetsel güç, yöneten-yönetilen ilişkisine yedirilerek meşrulaştırılmakta ve sıkı bir kontrol mekanizması ile yönetim faaliyeti kolaylaştırılmaktadır. Ayrıca kapitalist sistemin çalışanlar üzerinde yarattığı gelecek kaygısı, emeğin nitelikli hâle gelmesi için bir baskı unsuru oluşturmakta; yaşanan teknolojik gelişmeler de verimli ve üretken bir işgücü niteliğinin yanı sıra yenilikçi olmayı ve değişimlere hızlı bir biçimde uyum sağlamayı zorunlu kılmaktadır. İşverenler tarafından belirsizlik ve esnekliğin ön plana çıkarılması, işgücünün özgürleşmesi görünümü altında yönetsel meşruiyet alanını genişletme çabasını sürdürmekte ve rekabetin kutsallaştırıldığı günümüz çalışma yaşamında kılıfına uydurulmuş yönetimci uygulamalar, çalışanları manipüle edip metalaştırarak emek sömürüsünün önünü açmaktadır (Keskin, 2016).

Ulaşılan bu sonuçların, örgütsel davranış ve insan kaynakları yönetimi çerçevesinde istihdam ilişkilerinin daha iyi anlaşılmasında yol gösterici olduğu söylenebilir. Bu bağlamda, çalışanlar tarafından psikolojik sözleşme kapsamında yöneticilerin örgütün bir temsilcisi olarak konumlandırılmaları, psikolojik sözleşme kapsamındaki beklentilerin çoğunlukla işe alım ve insan kaynakları uygulamaları aracılığıla biçimlenmesi ile özellikle çalışanların psikolojik sözleşme kapsamındaki beklentileri hakkında yöneticileriyle yaşadıkları algısal uyumsuzluklar günümüz çalışma yaşamında öne çıkan işveren markası, çalışan değer önermesi, çalışan deneyimi odaklı bir örgüt kültürü yaratılması, yetenek yönetimi, kuşak farklılıklarının yönetimi ve tersine mentorluk gibi uygulamaların başarısı açısından önemli ipuçları taşımaktadır. Ayrıca çalışanların örgütten psikolojik sözleşme kapsamında beklediklerini elde edememeleri, özellikle psikolojik sözleşmenin bozulması ve ihlâli sürecinin aydınlığa kavuşturulmasında, öncülleri ve çalışanlar ile örgütler üzerindeki etkileri bakımından odaklanılması gereken hususların başında gelmektedir. Bu noktada, psikolojik sözleşmenin, tarafların örgütsel davranışlarını yönlendirdiği göz önüne alındığında, örgütün yükümlülüklerini yerine getirmediği algısı taşıyan çalışanların güçlü duygusal ve davranışsal tepkiler göstermesi şaşırtıcı olmayacaktır. Diğer taraftan, söz konusu araştırmanın çalışma grubunun "çalışma yaşamında düşük maaşla istihdam edilen yeni mezun mühendis olmak" ölçütü temelinde oluşturulmuş olması ve böylelikle ilgili yazındaki araştırmalarda göreceli olarak ihmal edilmiş spesifik bir çalışan kesimi ile yöneticilerinin iş ilişkisi çerçevesinde birbirlerinden yazılı olmayan beklentilerine dair karşı1lıklı algılarını yansıtan katılımcı ifadeleri içermesi, eğitim ve istihdam politikaları bağlamında da dikkate alınması gereken değerlendirmeler sunmaktadır. 
Bu çerçevede söz konusu çalışmanın; psikolojik sözleşmelerin oluşum sürecine ve kapsamına 1şık tutarak, ilgili yazında olgunun doğasına yönelik derinlemesine bir anlayış geliştirilmesine katkıda bulunduğu ifade edilebilir. Ayrıca tek taraflı bir bakış açısına odaklanmaktansa, psikolojik sözleşmenin tarafı olan tüm kesimlerin araştırmaya dâhil edilmesi ve yorumsamacı bir yaklaşım tarzıyla ilgili tarafların psikolojik sözleşme kapsamındaki karşılıklı beklenti ve yükümlülüklerine dair algılarının neleri içerdiği hususunda kendileriyle doğrudan görüşülmesi bakımından bu araştırmanın, konuyla ilgili daha geniş kapsamlı bir bakış açısı ortaya konulmasına ve psikolojik sözleşme olgusuna yönelik bütünsel bir yapı sunulmasına olanak sağladığı düşünülmektedir. Diğer taraftan, söz konusu çalışmanın; pür nitel bir anlayışla araştırma sorunsalını bireysel, bağlamsal, yapısal ve kültürel koşullardan soyutlamadan irdelemesi temelinde mevcut psikolojik sözleşme araştırmalarındaki yaygın nicel eğilimden farklı bir araştırma deseni ortaya koyarak ulaştı̆̆ de daha sonraki psikolojik sözleşme çalışmaları açısından rehber niteliği taşıdığı söylenebilir.

$\mathrm{Bu}$ araştırmanın sonuçları, çalışma grubunda yer alan katılımcılardan elde edilen veriler ile sınırlıdır. Söz konusu kısıtlılıklar temelinde, konuya ilişkin daha sonraki araştırmalarda psikolojik sözleşmelerin gelişmesi, şekillenmesi, devam ettirilmesi, değişmesi, bozulması, ihlâli ve çalışanlar ile örgütler üzerindeki etkileri gibi meselelere hem kavramsal hem de görgül olarak derinlik kazandırılması önem taşımaktadır. Bu doğrultuda yapılacak olan görgül çalışmalarda tek taraflı bakış açısı yansıtılmasından ziyade, mümkün olduğunca psikolojik sözleşmenin tarafı olan tüm kesimlerin araştırmaya dâhil edilmesi önerilebilir. Ayrıca psikolojik sözleşmeye dair algıların zaman içindeki değişiminin ortaya çıkarılabilmesi adına ilgili yazında boylamsal araştırma tasarımlarına ihtiyaç duyulmaktadır. Konuya ilişsin araştırılmayı bekleyen yeni sorulara yanıt aranırken karma yöntemler kullanılmasının, bağlamsal unsurları dikkate alan özgün ölçme araçları geliştirilmesinin ve kültürlerarası karşılaştırmalı çalışmalar için uygun zemin hazırlanmasının da ilgili yazına değerli katkılar sunacağı düşünülmektedir.

\section{KAYNAKÇA}

AKAR, N. (2017a). "Mavi Yakalı Çalışanların Psikolojik Sözleşmeye İlişkin Algılarının Oluşumu ve Kapsamı Üzerine Nitel Bir Araştırma”. V. Örgütsel Davranış Kongresi Bildiriler Kitabı (1-7).

AKAR, N. (2017b). "İşverenler ile Mavi Yakalı Çalışanların Psikolojik Sözleşme Kapsamındaki Karşılıklı Beklenti ve Yükümlülüklerine Dair Algılarının Belirlenmesi”. Uluslararası Multidisipliner Çalışmaları Kongresi Bildiriler Kitabı (239-245).

ANDERSON, N., \& SCHALK, R. (1998). "The Psychological Contract in Retrospect and Prospect". Journal of Organizational Behavior, 19: 637-647.

ARAS, M., KARAKİRAZ, A., BAYRAKTAROĞLU, S., \& ÖZEN KUTANIS, R. (2016). "Türkiye'de Psikolojik Sözleşme Çalışmalarının Genel Görünümü”, R. ÖZEN KUTANIS (Ed.), Türkiye'de Örgütsel Davranış Çalışmaları II (47-67), Gazi Kitabevi, Ankara. 
CONWAY, N., \& BRINER, R. B. (2005). Understanding Psychological Contracts at Work: A Critical Evaluation of Theory and Research, Oxford University Press, USA.

COYLE-SHAPIRO, J. A. M., \& KESSLER, I. (2002). "Exploring Reciprocity Through the Lens of the Psychological Contract: Employee and Employer Perspectives". European Journal of Work and Organizational Psychology, 11(1): 69-86.

CRESWELL, J. W. (2007). Qualitative Inquiry and Research Design: Choosing Among Five Approaches. Sage Publications, Thousand Oaks California.

FREESE, C., \& SCHALK, R. (1996). "Implications of Differences in Psychological Contracts for Human Resource Management". European Journal of Work and Organizational Psychology, 5(4): 501-509.

GUEST, D. E. (2004). “The Psychology of the Employment Relationship: An Analysis Based on the Psychological Contract”. Applied Psychology: An International Review, 53(4): 541-555.

GUEST, D. E., \& CONWAY, N. (2002). “Communicating the Psychological Contract: An Employer Perspective”. Human Resource Management Journal, 12(2): 22-38.

HERRIOT, P., MANNING, W. E. G., \& KIDD, J. M. (1997). "The Content of the Psychological Contract”. British Journal of Management, 8(2): 151-162.

HOFSTEDE, G. (1980). Culture's Consequences: International Differences in Work-Related Values. Sage Publications, Beverly Hills California.

HUSSERL, E. (2010). Fenomenoloji Üzerine Beş Ders. H. TEPE (Çev.). Bilgesu Yayıncılık, Ankara.

KESKİN, U. (2016). “Çalışma Yaşamına Bakış Açılarının Tarihsel Süreçteki Değişimi ve Yönetimcilik (Managerializm) Anlayışının Yükselişi”. İşletme Araştırmaları Dergisi, 8(3): 1-18.

KOTTER, J. P. (1973). "The Psychological Contract: Managing the Joining-up Process". California Management Review, 15(3): 91-99.

MARKS, A. (2001). "Developing a Multiple Foci Conceptualization of the Psychological Contract”. Employee Relations, 23(5): 454-467.

McDermotT, A. M., CONWAY, E., ROUSSEAU, D. M., \& FlOOD, P. C. (2013). "Promoting Effective Psychological Contracts Through Leadership: The Missing Link Between HR Strategy and Performance". Human Resource Management, 52(2): 289310 .

MOUSTAKAS, C. (1994). Phenomenological Research Methods. Sage Publications, Thousand Oaks California.

MÖLLER, I-L. (2014). Managers' Awareness of Lower Echelon Employees' Perceptions of the Psychological Contract. (Unpublished Master's Dissertation). University of Pretoria, South Africa. 
ÖZDAŞLI, K., \& ÇELİKKOL, Ö. (2012). "Psikolojik Sözleşme: Kavramsal Çerçeve ve Bir İçerik Analizi”. Mehmet Akif Ersoy Üniversitesi Sosyal Bilimler Enstitüsü Dergisi, 4(7): 141-154.

RANDMANN, L. (2013). "Managers on the Both Sides of the Psychological Contract". Journal of Management and Change, 30(31): 124-144.

ROBINSON, S. L. (1996). "Trust and Breach of the Psychological Contract". Administrative Science Quarterly, 41(4): 574-599.

ROUSSEAU, D. M. (1989). "Psychological and Implied Contracts in Organizations". Employee Responsibilities and Rights Journal, 2(2): 121-139.

ROUSSEAU, D. M. (1990). "New Hire Perception of Their Own and Their Employer's Obligations: A Study of Psychological Contracts". Journal of Organizational Behavior, 11(5): 389-400.

ROUSSEAU, D. M. (2001). "Schema, Promise and Mutuality: The Building Blocks of the Psychological Contract”. Journal of Occupational and Organizational Psychology, 74: 511-541.

ROUSSEAU, D. M., \& GRELlER, M. M. (1994). "Human Resource Practices: Administrative Contract Makers”. Human Resource Management, 33(3): 385-401.

ROUSSEAU, D. M., \& TIJORIWALA, S. A. (1998). “Assessing Psychological Contracts: Issues, Alternatives and Measures". Journal of Organizational Behavior, 19(1): 679695.

SHERMAN, U. P., \& MORLEY, M. J. (2015). "On the Formation of the Psychological Contract: A Schema Theory Perspective". Group \& Organization Management, 40(2): 160-192.

SHORE, L. M., \& TETRICK, L. E. (1994). “The Psychological Contract as an Explanatory Framework in the Employment Relationship", C. L. COOPER \& D. M. ROUSSEAU (Ed.), Trends in Organizational Behavior, Vol. 1, (91-109), John Wiley \& Sons, Chichester.

TEKLEAB, A. G., \& TAYLOR, M. S. (2003). “Aren't There Two Parties in an Employment Relationship? Antecedents and Consequences of Organization-Employee Agreement on Contract Obligations and Violations". Journal of Organizational Behavior, 24: 585 608.

YAPICI-AKAR, N. (2010). "Psikolojik Sözleşme İhlalleri Bağlamında Örgütsel Sinizm Üzerine Kuramsal Bir Araştırma”. 1. Turizmde İnsan Kaynakları Gelişimi Sempozyumu Bildiriler Kitabı (43-60).

YILDIRIM, A., \& ŞİMŞEK, H. (2011). Sosyal Bilimlerde Nitel Araştırma Yöntemleri. Seçkin Yayıncılık, Ankara.

Bu makale, Akdeniz Üniversitesi Sosyal ve Beşeri Bilimler Bilimsel Araştırma ve Yayın Etiği Kurulu'nun 02.03.2020 tarihli ve 55 sayll kararı ile fikri hukuki ve telif hakları bakımından etik olarak uygun bulunmuştur. 